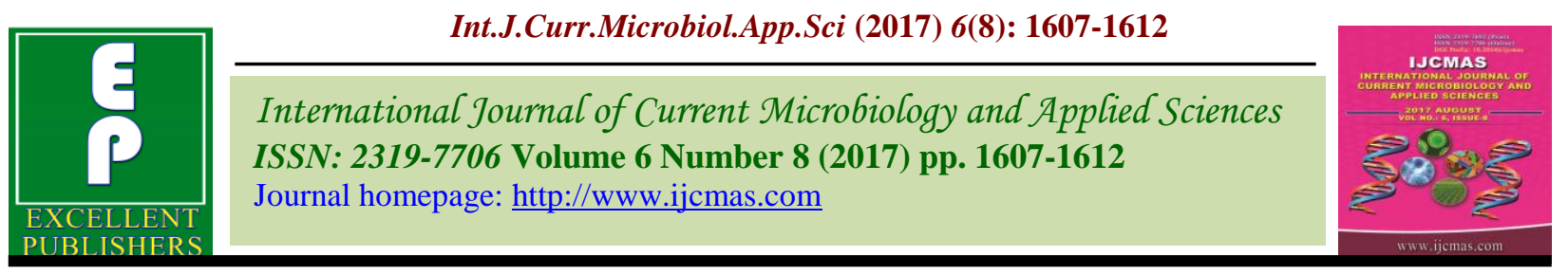

Original Research Article https://doi.org/10.20546/ijcmas.2017.608.193

\title{
Response of Wheat [Triticum aestivum (L.) emend. Fiori \& Paol.] Cultivars to Integrated Nutrient Management
}

\author{
R.R. Choudhary ${ }^{1 *}$, A.L. Prajapat $^{1}$, S.L. Choudhary ${ }^{2}$ and O.P. Meena ${ }^{1}$ \\ ${ }^{1}$ Rajasthan Agricultural Research Institute, (SKNAU) Jobner, Jaipur, Rajasthan, India \\ ${ }^{2}$ Department of Agronomy, Sri Karan Narendra Agriculture University, Jobner, Rajasthan, India \\ *Corresponding author
}

\section{A B S T R A C T}

\section{Keywords}

Wheat, INM,

Varieties,

Yield attributes,

$\mathrm{B}: \mathrm{C}$ ratio.

Article Info

Accepted:

17 June 2017

Available Online:

10 August 2017
The field experiment was conducted at research farm, Rajasthan Agricultural Research Institute, Durgapura, Jaipur for two consecutive years during rabi seasons 2014-15 and 2015-16 on loamy sand soil. The twenty four treatment combinations consisting of four varieties (PBW 502, Raj 4037, WH 1105 and HD 2967) and six integrated nutrient management practices (Farmer's practice, $100 \% \mathrm{RDF}, 100 \% \mathrm{RDF}+$ Azotobacter + PSB, $75 \% \mathrm{RDF}+$ Azotobacter $+\mathrm{PSB}, 75 \% \mathrm{RDF}+$ Azotobacter $+\mathrm{PSB}+\mathrm{ZnSO}_{4}$ and $50 \%$ $\mathrm{RDF}+25 \% \mathrm{~N}$ through organic manure + Azotobacter $+\mathrm{PSB}+\mathrm{ZnSO}_{4}$ ) were tested in factorial randomized block design with three replications. Results showed that variety $\mathrm{WH}$ 1105 proved significantly superior over HD 2967 and PBW 502 varieties with respect to yield attributes (Effective tiller per metre row length, number of grains per spike, length of spike and test weight) and yield and closely followed by variety Raj 4037. Results further indicated that number of effective tillers, grains per spike, grain, straw and biological yields significantly increased with application of $100 \%$ RDF + Azotobacter + PSB over farmer's practice but remained at par with $100 \%$ RDF. Significantly higher net returns and $\mathrm{B}: \mathrm{C}$ ratio was obtained with variety WH 1105 and application of $100 \% \mathrm{RDF}+$ Azotobacter + PSB independently.

\section{Introduction}

Wheat [Triticum aestivum (L.) emend. Fiori $\&$ Paol.] is the most important staple food crop of the world and emerged as the backbone of India's food security. It is grown all over the world for its wider adaptability and high nutritive value. It is an important winter cereal contributing about $38 \%$ of the total food grain production in India. Wheat straw is an important source of fodder for a large Indian animal population in India. Wheat and rice serve as life sustaining crops for our population and thus, considered to be the cornerstone of nation's food security system. However, there is need to further increase the production to fulfill the requirement of exploding population, maintenance of adequate buffer stock and to meet out demand for processing industries.

The rice-wheat cropping system of Indian agriculture is the cornerstone of the nation's food security. This system contributes about 75 percent of the nation's total food grain production (Yadav et al., 2005). It has tremendously helped the socio-economic development of the rural population in India. 
The green revolution in India during the late 1960s has no doubt brought about selfsufficiency in food grain production.

But currently, there is a growing concern about the sustainability of the rice-wheat cropping system as the growth rates of rice and wheat yields have either become stagnant or declined in rice-wheat growing states like Punjab, Haryana, eastern Uttar Pradesh, Madhya Pradesh, Bihar, Himachal Pradesh, Jammu and Kashmir as well as southern and other states. The dwarf varieties of wheat have great potential but due to exhaustive nature they require more nutrients and have posed a great threat to long-term sustainability of crop production.

\section{Materials and Methods}

The field experiment was conducted at research farm, Rajasthan Agricultural Research Institute, Durgapura, Jaipur for two consecutive years during rabi seasons 201415 and 2015-16 on loamy sand soil. The twenty four treatment combinations consisting of four varieties (PBW 502, Raj 4037, WH 1105 and HD 2967) and six integrated nutrient management practices (Farmer's practice, $100 \%$ RDF, $100 \%$ RDF + Azotobacter + PSB, $75 \% \mathrm{RDF}+$ Azotobacter + PSB, $75 \% \mathrm{RDF}+$ Azotobacter $+\mathrm{PSB}+\mathrm{ZnSO}_{4}$ and $50 \% \mathrm{RDF}+25 \% \mathrm{~N}$ through organic manure + Azotobacter $+\mathrm{PSB}$ $\left.+\mathrm{ZnSO}_{4}\right)$ were tested in Factorial Randomized Block Design (FRBD) with three replications.

The treatments were randomly allotted to different plots using random number table of Fisher and Yates (1963). The seed yield of each net plot (inclusive of tagged plants) was recorded in $\mathrm{kg}$ plot $^{-1}$ after cleaning the threshed produce was converted as $\mathrm{q} \mathrm{ha}^{-1}$. Straw yield was obtained by subtracting the seed yield $\left(\mathrm{q} \mathrm{ha}^{-1}\right)$ from biological yield $\left(\mathrm{q} \mathrm{ha}{ }^{-1}\right)$.

\section{Results and Discussion}

Data (Table 1) revealed that wheat variety WH 1105 recorded higher number of effective tiller per metre row length, number of grains per spike, length of spike and test weight, which was found at par with variety Raj 4037 during both the years and in pooled analysis. Data (Table 1) further indicated that application of $100 \%$ RDF + Azotobacter + PSB significantly increased the number of effective tiller per metre row length, number of grains per spike, length of spike and test weight during both the years and in pooled analysis over farmer's practice and was found at par with $100 \%$ RDF. Data (Table 2) revealed that wheat varieties differed significantly in the grain yield during both the year of experimentation and on pooled basis. Variety WH 1105 proved significantly superior as compared to other varieties during both the years of experimentation and recorded highest grain yield (44.86 $\mathrm{q} \mathrm{ha}^{-1}$ ) on the basis of pooled data and increased the grain yield by 7.26 and 15.14 percent as compared to variety HD 2967 and PBW 502, respectively but remained at par with variety Raj 4037 (44.44 q ha ${ }^{-1}$ ). Further, data showed that application of integrated nutrient management significantly increased grain yield of wheat as compared to farmer's practice during both the years of experimentation and in pooled data. Application of $100 \% \mathrm{RDF}+$ Azotobacter + PSB significantly increased the grain yield (45.22 $\mathrm{q} \mathrm{ha}^{-1}$ ) as compared to other treatments while, it proved at par with $100 \%$ RDF. On the basis of pooled data, $100 \%$ RDF + Azotobacter + PSB increased the grain yield by 17.12 per cent over farmer's practice, 5.11 per cent over $50 \% \mathrm{RDF}+25 \% \mathrm{~N}$ through organic manure + Azotobacter + PSB + $\mathrm{ZnSO}_{4}, 6.00$ per cent over $75 \% \mathrm{RDF}+$ Azotobacter $+\mathrm{PSB}+\mathrm{ZnSO}_{4}$ and 11.21 per cent over $75 \%$ RDF + Azotobacter + PSB. Straw and biological yields was found 
superior over variety HD 2967 and PBW 502 and $100 \% \mathrm{RDF}+$ Azotobacter + PSB was recorded higher value of straw and biological yields.

The overall improvement in crop growth under the influence of optimum nutrition involving combination of all nutrients and increasing role of fertility levels could be ascribed to their potential role in modifying soil and plant environment conducive for better development of both physiological and biochemical components of the plant growth that increase efficiency of physiological processes of plant system. Amongst nutrients, nitrogen is considered to be a vitally important plant nutrient. It is necessary for chlorophyll synthesis and as a part of the chlorophyll molecule, which is the primary absorber of light energy needed for photosynthesis. Lack of $\mathrm{N}$ and chlorophyll means the crop will not utilize sunlight as an energy source to carry on essential function such as nutrient uptake. It is a component of vitamins and energy systems in plants. Nitrogen is an essential component of amino acids, which form plant proteins. Besides these, it is also a constituent of certain organic compounds of physiological importance (Brady and Well, 2002; Havlin et al., 2006).

Further, phosphorous also improves the various metabolic and physiological processes thus known as "energy currency" which is subsequently used for vegetative and reproductive growth through phosphorylation. In addition to this vital metabolic role, $\mathrm{P}$ is an important structural component of nucleic acid, phytin, phospholipids and enzymes. An adequate supply of phosphorous early in the life cycle of plant is important in laying down the primordia for its reproductive part. It also increases the initiation of both first and second rootlets and their development. The extensive root system helps in exploiting the maximum nutrients and water from the soil
(Tondon, 1987). Whereas, $\mathrm{K}$ is not a structural part of any molecules inside the plant but it is necessary to many plant functions, including carbohydrate metabolism, enzyme activation, osmotic regulation and efficient use of water, $\mathrm{N}$ uptake and protein synthesis and translocation of assimilates. Besides these, it also has a role in decreasing certain plant diseases, improving quality and reducing the lodging of crop (Kumar et al., 2010). Further, Zinc plays important role in synthesis of various enzymes, $\mathrm{N}$ metabolism and several oxidation-reduction reactions. Further, synergistic interactions between these nutrients particularly $\mathrm{Zn}$ with primary nutrients (NPK) on growth and development of plants were also noted (Raghav et al., 2011; Singh et al., 2011).

Since, wheat yield formation is a complex process and governed by interaction between source (photosynthesis and availability of assimilates) and sink component (storage organs). Thus, as a consequence of marked improvement in both these regulative process as evidenced from higher accumulation of biomass and nutrients as well as yield components under variety WH 1105 led to significant increase in grain yield. Further, the grain yield of wheat is dependent on two most important components namely grains per unit area and weight of grains (test weight). Thus, due to more number of grains by virtue of increased number of spikes and more test weight under WH 1105, increased the grain yield over HD 2967 and PBW 502, But at par with variety Raj 4037. Since, biological yield is a sum of grain and straw yield produced by the crop, the increased grain yield under WH 1105 might have resulted in higher biological yield in this variety. The marked variation in various yield components and yield between varieties was observed by Pandey et al., (1999), Nainwal (2000), Sardana (2001) and Singh et al., (2007). 
Int.J.Curr.Microbiol.App.Sci (2017) 6(8): 1607-1612

Table.1 Effect of varieties and integrated nutrient management on yield attributes of wheat

\begin{tabular}{|c|c|c|c|c|c|c|c|c|c|c|c|c|}
\hline \multirow[t]{2}{*}{ Treatments } & \multicolumn{3}{|c|}{$\begin{array}{l}\text { Effective tillers } \\
\left(\mathrm{m}^{-1} \text { row length) }\right.\end{array}$} & \multicolumn{3}{|c|}{ Length of spike $(\mathrm{cm})$} & \multicolumn{3}{|c|}{ Number of grains spike ${ }^{-1}$} & \multicolumn{3}{|c|}{ Test weight $(\mathrm{g})$} \\
\hline & 2014-15 & $2015-16$ & Pooled & 2014-15 & $2015-16$ & Pooled & 2014-15 & $2015-16$ & Pooled & 2014-15 & $2015-16$ & Pooled \\
\hline \multicolumn{13}{|l|}{ Varieties } \\
\hline PBW 502 & 59.10 & 61.55 & 60.33 & 9.71 & 9.88 & 9.80 & 37.74 & 38.44 & 38.09 & 35.20 & 35.62 & 35.41 \\
\hline Raj 4037 & 67.51 & 68.39 & 67.95 & 10.75 & 11.39 & 11.07 & 40.88 & 42.93 & 41.91 & 37.45 & 37.49 & 37.47 \\
\hline WH 1105 & 68.23 & 68.52 & 68.38 & 10.92 & 11.49 & 11.21 & 40.96 & 43.00 & 41.98 & 37.59 & 37.65 & 37.62 \\
\hline HD 2967 & 63.19 & 65.05 & 64.12 & 10.19 & 10.65 & 10.42 & 39.22 & 40.71 & 39.97 & 37.08 & 37.12 & 37.10 \\
\hline SEm \pm & 0.91 & 0.95 & 0.66 & 0.14 & 0.20 & 0.12 & 0.48 & 0.53 & 0.36 & 0.56 & 0.50 & 0.38 \\
\hline $\mathrm{CD}(\mathrm{P}=0.05)$ & 2.60 & 2.71 & 1.85 & 0.39 & 0.57 & 0.34 & 1.38 & 1.51 & 1.01 & 1.59 & 1.43 & 1.06 \\
\hline \multicolumn{13}{|l|}{ Integrated nutrient management } \\
\hline Farmer's practice & 57.88 & 58.41 & 58.14 & 9.24 & 9.11 & 9.18 & 36.45 & 36.62 & 36.54 & 34.40 & 34.33 & 34.36 \\
\hline $100 \% \mathrm{RDF}$ & 68.90 & 70.13 & 69.52 & 11.05 & 11.94 & 11.50 & 41.78 & 44.22 & 43.00 & 37.71 & 37.72 & 37.71 \\
\hline $100 \% \mathrm{RDF}+$ Azotobacter + PSB & 69.17 & 70.46 & 69.81 & 11.18 & 11.99 & 11.58 & 41.85 & 44.31 & 43.08 & 37.87 & 37.75 & 37.81 \\
\hline $75 \% \mathrm{RDF}+$ Azotobacter $+\mathrm{PSB}$ & 61.04 & 62.82 & 61.93 & 9.88 & 10.08 & 9.98 & 38.17 & 39.19 & 38.68 & 36.39 & 37.13 & 36.76 \\
\hline $\begin{array}{l}75 \% \mathrm{RDF}+\text { Azotobacter }+\mathrm{PSB}+ \\
\mathrm{ZnSO}_{4}\end{array}$ & 64.88 & 66.67 & 65.78 & 10.46 & 10.94 & 10.70 & 39.87 & 41.54 & 40.71 & 37.14 & 37.41 & 37.27 \\
\hline $\begin{array}{l}50 \% \mathrm{RDF}+25 \% \mathrm{~N} \text { through } \\
\text { organic manure }+ \text { Azotobacter }+ \\
\mathrm{PSB}+\mathrm{ZnSO}_{4}\end{array}$ & 65.17 & 66.77 & 65.97 & 10.55 & 11.05 & 10.80 & 40.08 & 41.73 & 40.91 & 37.47 & 37.49 & 37.48 \\
\hline SEm \pm & 1.12 & 1.16 & 0.81 & 0.17 & 0.24 & 0.15 & 0.59 & 0.65 & 0.44 & 0.68 & 0.62 & 0.46 \\
\hline $\mathrm{CD}(\mathrm{P}=0.05)$ & 3.18 & 3.32 & 2.27 & 0.48 & 0.69 & 0.42 & 1.69 & 1.85 & 1.24 & 1.95 & 1.75 & 1.29 \\
\hline
\end{tabular}


Table.2 Effect of varieties and integrated nutrient management on yield of wheat

\begin{tabular}{|c|c|c|c|c|c|c|c|c|c|}
\hline \multirow[t]{2}{*}{ Treatments } & \multicolumn{3}{|c|}{ Grain yield $\left(\mathrm{q} \mathrm{ha}^{-1}\right)$} & \multicolumn{3}{|c|}{ Straw yield $\left(\mathrm{q} \mathrm{ha}^{-1}\right)$} & \multicolumn{3}{|c|}{ Biological yield $\left(\mathrm{q} \mathrm{ha}^{-1}\right)$} \\
\hline & $2014-15$ & $2015-16$ & Pooled & $2014-15$ & 2015-16 & Pooled & 2014-15 & $2015-16$ & Pooled \\
\hline \multicolumn{10}{|l|}{ Varieties } \\
\hline PBW 502 & 38.16 & 39.76 & 38.96 & 55.11 & 57.44 & 56.28 & 93.27 & 97.20 & 95.24 \\
\hline Raj 4037 & 43.55 & 45.33 & 44.44 & 64.15 & 67.48 & 65.82 & 107.70 & 112.81 & 110.26 \\
\hline WH 1105 & 43.91 & 45.81 & 44.86 & 64.88 & 67.93 & 66.41 & 108.79 & 113.74 & 111.27 \\
\hline HD 2967 & 41.05 & 42.59 & 41.82 & 59.34 & 63.11 & 61.23 & 100.39 & 105.70 & 103.05 \\
\hline $\mathrm{SEm} \pm$ & 0.51 & 0.57 & 0.38 & 0.98 & 1.06 & 0.72 & 1.29 & 1.57 & 1.02 \\
\hline $\mathrm{CD}(\mathrm{P}=0.05)$ & 1.44 & 1.61 & 1.07 & 2.80 & 3.03 & 2.03 & 3.66 & 4.48 & 2.86 \\
\hline \multicolumn{10}{|l|}{ Integrated nutrient management } \\
\hline Farmer's practice & 37.91 & 39.30 & 38.61 & 53.98 & 56.43 & 55.20 & 91.88 & 95.73 & 93.81 \\
\hline $100 \% \mathrm{RDF}$ & 44.02 & 45.89 & 44.95 & 65.17 & 68.57 & 66.87 & 109.19 & 114.45 & 111.82 \\
\hline $\begin{array}{l}100 \% \mathrm{RDF}+\text { Azotobacter }+ \\
\mathrm{PSB}\end{array}$ & 44.31 & 46.13 & 45.22 & 65.45 & 68.71 & 67.08 & 109.76 & 114.85 & 112.31 \\
\hline $\begin{array}{l}75 \% \mathrm{RDF}+\text { Azotobacter }+ \\
\mathrm{PSB}\end{array}$ & 39.84 & 41.47 & 40.66 & 57.67 & 60.67 & 59.17 & 97.51 & 102.14 & 99.83 \\
\hline $\begin{array}{l}75 \% \mathrm{RDF}+\text { Azotobacter }+ \\
\mathrm{PSB}+\mathrm{ZnSO}_{4}\end{array}$ & 41.72 & 43.60 & 42.66 & 61.35 & 64.71 & 63.03 & 103.08 & 108.30 & 105.69 \\
\hline $\begin{array}{l}50 \% \mathrm{RDF}+25 \% \mathrm{~N} \text { through } \\
\text { organic manure }+ \\
\text { Azotobacter }+\mathrm{PSB}+\mathrm{ZnSO}_{4}\end{array}$ & 42.19 & 43.84 & 43.02 & 61.60 & 64.85 & 63.23 & 103.80 & 108.70 & 106.25 \\
\hline $\operatorname{SEm} \pm$ & 0.62 & 0.69 & 0.47 & 1.20 & 1.30 & 0.89 & 1.58 & 1.93 & 1.25 \\
\hline $\mathrm{CD}(\mathrm{P}=0.05)$ & 1.77 & 1.97 & 1.31 & 3.42 & 3.71 & 2.49 & 4.48 & 5.49 & 3.50 \\
\hline
\end{tabular}

Table. 3 Effect of varieties and integrated nutrient management on net returns and B:C ratio

\begin{tabular}{|c|c|c|c|c|c|c|}
\hline \multirow[t]{2}{*}{ Treatments } & \multicolumn{3}{|c|}{ Net returns $\left(\mathrm{Rs} \mathrm{ha}^{-1}\right)$} & \multicolumn{3}{|c|}{$\mathrm{B}: \mathrm{C}$ ratio } \\
\hline & $2014-15$ & $2015-16$ & Pooled & 2014-15 & $2015-16$ & Pooled \\
\hline \multicolumn{7}{|l|}{ Varieties } \\
\hline PBW 502 & 64868 & 68986 & 66927 & 1.96 & 2.09 & 2.03 \\
\hline Raj 4037 & 79455 & 84479 & 81967 & 2.40 & 2.56 & 2.48 \\
\hline WH 1105 & 80505 & 85565 & 83035 & 2.44 & 2.59 & 2.51 \\
\hline HD 2967 & 72319 & 77199 & 74759 & 2.19 & 2.34 & 2.26 \\
\hline SEm \pm & 987 & 1183 & 770 & 0.04 & 0.05 & 0.03 \\
\hline $\mathrm{CD}(\mathrm{P}=0.05)$ & 2809 & 3368 & 2163 & 0.12 & 0.15 & 0.09 \\
\hline \multicolumn{7}{|l|}{ Integrated nutrient management } \\
\hline Farmer's practice & 66575 & 70419 & 68497 & 2.20 & 2.33 & 2.25 \\
\hline $100 \% \mathrm{RDF}$ & 80690 & 85898 & 83294 & 2.43 & 2.58 & 2.50 \\
\hline $100 \% \mathrm{RDF}+$ Azotobacter $+\mathrm{PSB}$ & 81115 & 86167 & 83641 & 2.42 & 2.57 & 2.50 \\
\hline $75 \% \mathrm{RDF}+$ Azotobacter $+\mathrm{PSB}$ & 70230 & 74799 & 72514 & 2.19 & 2.33 & 2.26 \\
\hline $75 \% \mathrm{RDF}+$ Azotobacter $+\mathrm{PSB}+\mathrm{ZnSO}_{4}$ & 74390 & 79584 & 76987 & 2.23 & 2.39 & 2.31 \\
\hline $\begin{array}{l}50 \% \mathrm{RDF}+25 \% \mathrm{~N} \text { through organic manure } \\
+ \text { Azotobacter }+\mathrm{PSB}+\mathrm{ZnSO}_{4}\end{array}$ & 72721 & 77477 & 75099 & 2.02 & 2.15 & 2.09 \\
\hline SEm \pm & 1208 & 1449 & 943 & 0.05 & 0.06 & 0.04 \\
\hline $\mathrm{CD}(\mathrm{P}=0.05)$ & 3440 & 4125 & 2650 & 0.15 & 0.18 & 0.11 \\
\hline
\end{tabular}


In conclusion, based on the results of two years experimentation, it may be concluded that wheat variety $\mathrm{WH}-1105$ out yielded and fetched significantly highest net returns and $\mathrm{B}$ : $\mathrm{C}$ ratio hence got the first preference which was closely followed by Raj-4037 (Table 3). Application of $100 \% \mathrm{RDF}+$ Azotobacter + PSB was found to be the most suitable integrated nutrient management practice. However, $100 \%$ RDF also proved equally effective.

\section{References}

Brady, N.C. and Well, R.R. 2002. The nature and properties of soil (13th Edition), Pearson Education (Singapore) Pvt. Ltd., New Delhi, India.

Fisher, R.A. and Yates, F. 1963. Statistical tables. Oliver and Boyd, Edinburgh, London.

Havlin, J.L., Beaton, J.D., Tisdale, S.L., Nelson, W.L., 2006. Soil fertility and fertilizer 7th Edition, Prentice Hall of India Pvt. Ltd., New Delhi pp. 45-79.

Kumar, M., Sheoran, P. and Yadav, A. 2010. Productivity potential of wheat (Triticum aestivum) in relation to different planting methods and nitrogen management strategies. Indian J. Agri. Sci., 80: 427-44

Nainwal, K. and Singh, M. 2000. Varietal behaviour of wheat (Triticum aestivum) to dates of sowing under Tarai region of Uttar Pradesh. Indian J. Agron.,
45(1): 107-113.

Pandey, I.B, Thakur, S.S and Singh, S.K. 1999. Response of timely sown wheat (Triticum aestivum) varieties to seed rate and fertility level. Indian J. Agron., 44(4):745-749.

Raghav, R.S., Chauhan, S.K., Singh, S.K. 2011. Response of wheat (Triticum aestivum) cultivars to potassium application. Annals of Agri. Res., 32: 59-60.

Sardana, V. 2001. Effect of different dose of nutrient on yield and mottling incidence of durum wheat (Triticum durum). Crop Res., Hisar 22: 134-137.

Singh, C.M., Sharma, P.K., Mishra, P.K., Singh, P.K., Rajhans, A.P. and Verma, R.P. 2011. Impact of integrated nutrient management on growth, yield and nutrient uptake by wheat (Triticum aestivum L.). Asian J. Agri. Res., 5: 7682.

Singh, R.K., Singh, S.K. and Singh, L.B. 2007. Integrated nitrogen management in wheat (Tritium aestivum). Indian J. Agron., 52: 124-126.

Tondon, H.L.S. 1987. Phosphorus research and agriculture production in India. Fertilizer Development and Constatation Organization, New Delhi. Yadav, D.S., Shukla, R.P. and Birendra, K. 2005. Effect of zero tillage and nitrogen levels on wheat (Triticum aestivum) after rice (Oryza sativa). Indian J. Agron., 50(1): 52-53.

\section{How to cite this article:}

Choudhary, R.R., A.L. Prajapat, S.L. Choudhary and Meena, O.P. 2017. Response of Wheat [Triticum aestivum (L.) emend. Fiori \& Paol.] Cultivars to Integrated Nutrient Management. Int.J.Curr.Microbiol.App.Sci. 6(8): 1607-1612. doi: https://doi.org/10.20546/ijcmas.2017.608.193 